\title{
WORLD-WIDE DISTRIBUTION OF THE BRYOZOAN PECTINATELLA MAGNIFICA (LEIDY 1851)
}

\author{
ZUZANA BALOUNOVÁ ${ }^{1}$, EVA PECHOUŠKOVÁ ${ }^{1}$, JOSEF RAJCHARD ${ }^{1, *}$, \\ VÍT JOZA ${ }^{1}$, and JAN ŠINKO ${ }^{2}$
}

${ }^{1}$ Faculty of Agriculture, University of South Bohemia, CZ 370 05, České Budějovice, Czech Republic

${ }^{2}$ Faculty of Fisheries and Protection of Waters, University of South Bohemia, CZ 389 01, Vodñany, Czech Republic

*Corresponding author: rajchard@zf.jcu.cz

\begin{abstract}
Pectinatella magnifica (Leidy 1851) is an invasive freshwater colonial animal belonging to the phylum Bryozoa. It is native to the area east of the Mississippi River, from Ontario to Florida. Currently it occurs throughout North America and the first record for it outside that continent was for Bille near Hamburg in 1883. Later, it was found in the Elbe (Havel by Spandau), in Tegeler See, a pond in Wroclaw and in Silesia and Brandenburg. In addition, floatoblasts of P. magnifica were found in the upper Elbe in Germany in the 1950s. Then, P. magnifica spread to the area of Spandau in Berlin and the Oder, and Wroclaw. It is also recorded in Romania and Turkey. In France, it was recorded occurring in the area called Franche-Comté in 1994. Its occurrence in the Netherlands was first reported in 2003 and then each following year. The newest discoveries are for the Rhine basin in the area between Luxembourg and Germany. Recently, it was also recorded in the Czech Republic and Austria. Besides Europe and North America, it is also recorded in Japan and Korea. The statoblasts of P. magnifica are spread by flowing water, zoochory and probably also by anthropochory.
\end{abstract}

Keywords: Europe, lake, North America, Pectinatella magnifica, river

\section{Characteristics of Pectinatella magnifica}

Pectinatella magnifica (Leidy 1851) is an invasive organism belonging to the phylum Bryozoa (Carroget et al. 2005). Bryozoans (syn. Ectoprocta, Polyzoa) are a group of tiny colonial invertebrate animals. They often occur in epibenthos and littoral bioceonoses (Rogick 1934; Rogick 1957; Bushnell et al. 1987; Ricciardi and Lewis 1991). Most species live in marine environments. According to the literature there are 94 freshwater species (Massard and Geimer 2008).

A colony is formed by zooids, each consisting of two parts: a body wall called cystid and polypide, wherein the viscera are located. Body cavities of the zooids in a colony interconnect with one another and individuality is suppressed. The exterior of the cystid consists of a layer of secretion, which can be e.g. chitin or a jelly-like substance. Colonies grow by budding and can reach sizes of from a few millimetres to several kilograms (Wood 1989). They are filter feeders, which feed mainly on plankton and detritus (Wood 2001) that they collect by means of a retractile ring of ciliated tentacles called a lophophore (Riisgård et al. 2004).

Leidy found and described Pectinatella magnifica in 1851 near Philadelphia. He placed it in the genus Cristatella and called this new species Cristatella magnifica. However, he soon discovered that this new species differs from others in the genus Cristatella and established the new genus for this species: Pectinatella (Opravilová 2005).

\section{Origin of Pectinatella magnifica}

Research on the freshwater bryozoan Pectinatella magnifica started in the early 20th century, (e.g. Daven- port 1904; Wilcox 1906; Braem 1911). Jullien (1885), who recorded the occurrence of $P$. magnifica in America in the Mississippi River in 1885, ignored the fact that it occurred in the Hamburg area and described it as species endemic to America. Loppens $(1908 ; 1910)$ records P. magnifica occurring in America and Europe, but did not comment on this fact. Davenport (1904) also records its occurrence outside America, e.g. in Germany (Borodin 1928). Most authors claim that P. magnifica comes from North America (e.g. Jullien 1885), although Borg (1930) does not exclude the possibility that it might have a cosmopolitan distribution. Lacourt (1968) thinks that its assumed import into Europe and Asia is uncertain.

Kraepelin $(1884 ; 1887)$ and Kafka (1887) did not doubt that Pectinatella magnifica originated from North America. They describe it as an unarctic species, which was accidentally introduced into Europe. At first it occurred only in the area of Hamburg. Hartmeyer (1909), who recorded its spread out of this area and records it in the Havel and Oder rivers, shared this opinion. Historical analyses of the records of this species in Europe indicate that the hypothesis of accidental introduction is the most probable and coherent, followed by spreading along navigable watercourses. Massard and Geimer (2002) also record the occurrence of the family Pectinatellidae in four zoogeographic areas - Palaearctic, Unarctic, Neotropic and Oriental (i.e. Pectinatella magnifica - Palaearctic: European part and part of Asia, Nearctic, Neotropic and Oriental). It has not been recorded in tropical Africa, Australasia or on Oceanic Islands in the Pacific (Rogick and Schalie 1950). 


\section{Worldwide distribution}

According to many authors Pectinatella magnifica is an autochthonous species characteristic of lentic areas, such as sluggish rivers and outflows from lakes in the eastern and partly also the central part of North America, roughly east of the Mississippi River, from Ontario to Florida. Occurrence outside this area is very likely only a result of it being introduced. It now appears to be well established all across North America, except in areas with a cold climate (Rogick and Schalie 1950; Lacourt 1968; Everitt 1975; Rodriguez and Vergon 2002).

There is a single record of statoblasts of Pectinatella magnifica in Guatemala (Lacourt 1968) and colonies in Japan (Mawatari 1973; Oda 1974; Rodriguez and Vergon 2002) and Korea (Seo 1998; Rodriguez and Vergon 2002).

Occurrence in the Southern Hemisphere is so far unknown.

P. magnifica was recorded in Rattlesnake Creek, a few miles from Buffalo (Kellicott 1882), the Mississippi River in 1885 (Jullien 1885) and in other states of the USA on the north-eastern coast of the Atlantic Ocean: Massachusetts, Maine and Mississippi (Kraepelin 1887). It was recorded in lakes near Coldspring Harbor in New York State in 1898 (Davenport 1898). Subsequently it was found in a relatively wide area in eastern USA. According to Davenport (1904) it now occurs from the Great Lakes on the border with Canada to Florida and from the Mississippi to the Atlantic Ocean.

Dendy (1963) states that P. magnifica is occasionally an abundant species in the Alabama ponds area and other studies indicate it also occurs in Ohio (Wood 1989), Michigan (Bushnell 1965), north-western Louisiana (Everitt 1975), Texas and the north-western Pacific area (Neck and Fullington 1983; Wood 2001). It is also recorded in north-western Indiana (Barnes and Lauer 2003).

Currently (from the 1990s), this bryozoan is reported from lakes along the north-western coast of USA in the states Michigan, Massachusetts, Pennsylvania, and Canada (Opravilová 2005).

\section{Occurrence in Europe}

The first record of this species outside North America was from Bille near Hamburg in 1883 (Zimmer 1906; Bernauer and Jansen 2006). Later it was recorded in the Elbe (Havel by Spandau) and the river basin of the Elbe (Tegeler See by Berlin) (Hrabě 1935).

It is also recorded as occurring in a pond of the zoological institute in Wroclaw, which is connected with the Oder River and in Silesia and Brandenburg (Hrabě 1935).

Floatoblasts of P. magnifica were recorded in the upper Elbe in Germany in the 1950s by Kothé (1961). That is, this species occurs in the Elbe and Havel in the area of Spandau in Berlin and the Oder near Wroclaw in Poland.
It is not easy to explain its occurrence in Romania and Turkey but it might indicate that this species is spreading into central and south-eastern Europe. It is interesting that it does not appear to be spreading in the opposite direction, into Western Europe. It is clear that the Mittelland canal, which connects the Elbe, Wesser, Ems and Rhine, does not provide a system of rivers and canals flowing to the east (Massard and Geimer 2002). Studies of d'Hondt and Condé (1996) and Notteghem (1999) did not explain how Pectinatella magnifica got to France. It probably first occurred in the canal de l'Est (Territoire de Belfort) and spread there from the east (d'Hondt and Condé 1996). Its presence in this area was confirmed in 1994 (Haute-Saone canal-Territoire Belfore) (Notteghem 1999). This canal follows the Rhone-Rhine canal, connecting the Rhine and the Elbe. Colonies of P. magnifica were discovered in an area called Franche-Comté in 1994. Gradual spread was later recorded in FrancheComté and surrounding regions (Rodriguez and Vergon 2002). It was found in a pond situated in the valley of the Moselle in France in 1995, first near Nomexy and later near Chatel-sur-Moselle in a slowly flowing part of the Moselle (d'Hondt and Condé 1996). It was recorded in the Oder between Küstrin and Hohensaaten in 1996 (Tittizer et al. 2000), by Bru in 1997 in the Meurthe basin, in a pond situated in the Monseigneur (a tributary of Mortagne) and in a pond situated in another tributary of the Mortagne in 1999 (Notteghem 1999). This author also records many colonies in Lake Sorme (Burgundy) in 1998. There are other reports of it occurring in four different hydro geographic areas, the Rhone, Saone and Rhone, Loire and Siena. Its occurrence near Nennig probably relates to previous occurrences in France, from where it could have been transported by the Mosselle (Germany-Luxembourg part). This canal was opened in 1964 (Massard and Geimer 2002).

Occurrence of P. magnifica in the Netherlands was reported first in April 2003 (Massard and Geimer 2002) and then each following year. However, it is not recorded as occurring in Luxembourg and neighbouring regions of Belgium, France and Germany (Geimer and Massard 1986) or in the Rhine (Franz 1992). Tittizer et al. (2000) also concludes that it is unlikely that the Rhine was the route via which $P$. magnifica spread into France (Massard and Geimer 2002). Instead, these authors hypothesize that its introduction into this area was via commercial fishing or ship transport. If this is correct, Pectinatella was introduced into the Rhine via French canals (RhoneRhine, Marne-Rhine (the upper Rhine) or the Moselle (the middle Rhine).

The most recent records of this species of bryozoan are for the Rhine basin, in the area between Luxembourg and Germany (Massard and Geimer 2002) and in France. It is reported in the following areas of France: Vosges in north-eastern France in 1996 and Belfort in the east and upper Saona (Rodriguez and Vergon 2002). Grabow 2005 records it occurring in the summer of 2003 in a former 
gravel pit connected to the Rhine, in Baden-Wuertemberg (Germany).

In summary, apart from its occurrence in USA and Canada $P$. magnifica is recorded occurring in Western and Central Europe (France, Luxembourg, Germany, Poland, Czech Republic and Austria (Kraepelin 1887; Lacourt 1968; Rodriguez and Vergon 2002; Devin et al. 2005; Bauer et al. 2010; Balounová et al. 2011), Romania (Lacourt 1968), Corsica (Notteghem 2009) and Asia Minor (Lacourt 1968).

Currently P. magnifica is spreading in France, Germany and the Czech Republic (Rodriguez and Vergon 2002; Bauer et al. 2010; Balounová et al. 2011).

\section{Mode of dispersal}

There is little information on the mode of dispersal of P. magnifica. The spread in slowly flowing streams is certainly significantly determined by the flow of the water (Rodriguez and Vergon 2002). According to Oda (1974) this species is also spread by zoochory (dispersal of statoblasts on feathers of birds). Dispersal by water animals and transport with fish (fingerling) in aquaculture is also probable (Osburn 1921; Seo 1998).

This species could have been spread from North America into Europe by shipping (Lacourt 1968). Another means of anthropochory might be the transport of fishing equipment (Seo 1998).

However, P. magnifica is mainly thought to be dispersed by transport along rivers on boats and between water reservoirs by water birds. The big anchors on the statoblasts enable them to attach to different objects in the water, such as ships and row-boats, and the feathers of birds. It is also possible that statoblasts of this species are spread in the droppings of birds because their viability is not changed by digestion (Opravilová 2005). It is recorded that $38 \%$ of the statoblasts of this species passed through the digestive system of Anas platyrhynchos unharmed (Brown 1933).

Statoblasts have been recorded in the stomach contents of fish, in particular young fish of Micropterus salmoides, Pomoxis annularis, Lepomis pallidus and Dorosoma capedianum (Osburn 1921; Brown 1933). Notteghem (1999) states that it is likely that P. magnifica is spread by introducing young fish into rivers and ponds. The spread of this species towards the west from western Texas occurred when water canals were constructed (Neck and Fullington 1983). (This spread was probably facilitated by a combination of transport by water birds and man.)

\section{Conclusion}

Pectinatella magnifica is a native of the area east of the Mississippi River, from Ontario to Florida. Currently it occurs throughout Northern America. It was first recorded outside North America in the River Bille near Hamburg in 1883. In Europe it currently occurs mainly in the basins of the Elbe, Oder and Rhine rivers in Germany, Poland, France (including Corsica), Czech Republic, Netherlands, Austria and Rumania. It is currently spreading in France, Germany and the Czech Republic. In addition to Europe it is also in Japan and Korea.

The above summary indicates that the spread of P. magnifica is not a local phenomenon, but has occurred in several areas simultaneously. The records indicate it is spreading mainly towards the east. It occurs regularly in Western Europe where its spread is restricted to local occupation of other suitable locations. Central Europe can be considered to be the area where this species first colonized Europe and the boundaries of its current distribution there are the basins of the Elbe and Vltava rivers with local intrusions into the Morava River basin. East and South Eastern Europe from Slovakia are considered to be potential areas for further spread.

It is assumed that anthropogenic factors such as shipping, construction of dams, connecting channels, exploitation of resources (e.g. gravel and sand) in swampy areas and the associated transport of mining equipment, tourism, recreation, water sports, etc. have contributed considerably to the spread of this species. A certain proportion of the spread of Pectinatella magnifica can be attributed to the natural dispersal of statoblasts, particularly by water birds. This may also be facilitated by human activities such as the construction of water works, which provide habitats for aquatic birds, including resting places for migratory birds. Due to the occurrence of Pectinatella magnifica in mainly relatively oligotrophic to mesotrophic waters, often used in different ways for recreational purposes, it is also likely that statoblasts are dispersed by these activities.

\section{Acknowledgements}

This study was funded by the South Bohemian Research Centre of Aquaculture and Biodiversity of Hydrocenoses (Grant No. CENAKVA CZ.1.05/2.1.00/01.0024 and GA JU 046/2010/Z), Czech Science Foundation (Grant No. P503/12/0337) and Grant Agency of the University of South Bohemia (Grants No. OPVK-CZ. 1.07/2.3.00/09.0076 and No. 107/2010/Z). We thank Dr. Sabina Nováková for improving the English of this paper.

\section{REFERENCES}

Balounová Z, Rajchard J, Švehla J, Šmahel L (2011) The onset of invasion of bryozoan Pectinatella magnifica in South Bohemia (Czech Republic). Biologia 66: 1091-1096.

Barnes DK, Lauer TE (2003) Distribution of freshwater sponges and bryozoans in northwest Indiana. Proc Indiana Acad Sci 112: 29-35. 
Bauer C, Johanna M, Šetlíková I (2010) Das Moostierchen Pectinatella magnifica in Österreich. Österreichs Fisch 63: 262-264.

Bernauer D, Jansen W (2006) Recent invasions of alien macroinvertebrates and loss of native species in the upper Rhine river. Ger Aquat Invasion 1: 55-71.

Borg F (1930) Moostierchen oder Bryozoen (Ectoprocten). In: Bischoff $\mathrm{H}$ (ed.) Muschelinge oder Moluscocieda und Manteltiere oder Tunicata (Kamptozoa, Phoronidea, Bryozoa, Tunicata, Ascidiae). Die Tierwelt Deutschlands und der angrenzenden Meersteile nach ihren Merkmalen und nach ihrer Lebensweise. Jena Gustav Fisher, pp. 25-142.

Borodin N (1928) Notes on Pectinatella magnifica Leidy. Zool Jahrb Syst Oekol Georg 54: 487-494.

Braem F (1911) Die Variation bei den Statoblasten von Pectinatella magnifica. Arch Entw Mech Org 32: 314-348.

Brown CJD (1933) A limnological study of certain fresh-water Polyzoa with special reference to their statoblasts. Trans Am Microsc Soc 52: 271-314.

Bushnell JH, Foster SQ, Wahle BM (1987) Annotated inventory of invertebrate populations in an alpine lake and stream chain in Colorado Gt Basin. Naturakiust 47: 500-511.

Bushnell JH (1965) On the taxonomy and distribution of freshwater Ectoprocta in Michigan. Part. I. Trans Am Microsc Soc 84: 231-244.

Carroget P, Carroget L, Gruet Y, Baudet J, Dutertre M (2005) Presence of colonies of the bryozoan Pectinatella magnifica Leidy 1851 in the Loire and the Nantes channel at Brest (Loire-Atlantique). Bull Soc Sci Naturelles Ouest Fr Bull Soc 27: 19-29.

Davenport CB (1898) The fauna and flora about Coldspring Harbor, L.I. Science 8: 685-689.

Davenport CB (1904) Report on the fresh-water Bryozoa of the United States. Proc US Natnl Mus Wash 27: 211-222.

Dendy JS (1963) Observations on bryozoan ecology in farm ponds. Limnol Oceanogr 8: 478-482.

Devin S, Bollache L, Noël PY, Beisel JN (2005) Patterns of biological invasions in French freshwater systems by non-indigenous macroinvertebrates. Hydrobiol 551: 137-146.

Everitt B (1975) Fresh-water Ectoprocta: distribution and ecology of five species in southeastern Louisiana. Trans Am Micros Soc 94: $130-134$.

Franz HW (1992) Der Rhein und seine Besiedlung im Wandel schwebstoffzehrende Organismen (Hydrozoa, Kamptozoa und Bryozoa) als Indikatoren für den Ekologischen Zustand eines Gewassers. Pollichia B 25: 1-167.

Geimer G, Massard JA (1986) Les Bryozoaires du Grand-Duché de Luxembourg et des régions limitrophes. Trav Scient Mus Hist Nat Lux 7: 1-188.

Grabow K (2005) Pectinatella magnifica (Leidy, 1851) (Bryozoa) at the Upper Rhine, Germany. Lauterb 19: 133-139.

Hartmeyer R (1909) Bryozoen, Moostierchen. In: Brauer A (ed.) Süßwasserfauna von Deutschlands. Jena, Gustav Fischer, pp. 49-58.

d'Hondt J, Condé B (1996) Une espéce de Bryozoaires d'eau douce (Phylactolaemates) nouvelle pour la faune française: Pectinatella magnifica (Leidy 1851), Bull Mens Soc Linn Lyon 65: 322-326.

Hrabě S (1935) O Pectinatella magnifica a některých jiných mechovkách. Věda Př́rodní 16: 89-92.

Jullien J (1885) Monographie des Bryozoaires d'eau douce. Bull Soc Zool Fr 10: 91-207.

Kafka J (1887) Die Süßwasserbryozoen Böhmens. Arch Naturw Landesdurchf Böhmens 6: 1-79.

Kellicott DS (1882) Polyzoa: Observations on Species Detected near Buffalo. NY Proc Am Soc Microsc 4: 217-229.
Kothé P (1961) Hydrobiologie der Oberelbe. Natürliche, industrielle und wasserwirtschaftliche Faktoren in ihrer Auswirkung auf das Benthos des Stromgebietes oberhalb Hamburgs. Arch Hydrobiol Suppl 26: 221-343.

Kraepelin K (1884) Zur Biologie und Fauna der Süßwasserbryozoen. Zool Anz 7: 319-321.

Kraepelin K (1887) Die deutschen Süßsswasserbryozoen. I. Anatomisch-systematischer Teil Abh Geb Naturwiss hrsg Naturwiss Ver 10: 1-168.

Lacourt AW (1968) A monograph of the freshwater Bryozoa Phylactolaemata. Zool Verhandel 93: 1-159.

Loppens K (1908) Les Bryozoaires d'eau douce. Ann Biol Lacustre 3: $141-183$

Loppens K (1910) Fauna aquatica europaea. Les Bryozoaires d'eau douce d'Europe. Ann Biol Lacustre 4: 139-161.

Massard JA Geimer G (2002) Occurence of Pectinatella magnifica (Leidy, 1851) (Bryozoa, Phylactolaemata) in the German-Luxemburg border region near Bech-Kleinmacher (Luxemburg) and Nennig (Germany). Arch 44: 107-120.

Massard JA, Geimer G (2005) Die Süßwasserbryozoen in der Fauna Europaea 2004: Karten und Kommentare. Denisia 16: 167-174.

Massard JA, Geimer G (2008) Global diversity of bryozoans (Bryozoa or Ectoprocta) in freshwater: an update. Bull Soc Natliste Luxemb 109: 139-148.

Mawatari S (1973) New occurrence of Pectinatella magnifica (Leidy) in a Japanese lake. Proc Japan Soc Systematic Zool 9: 41-43.

Neck R, Fullington R (1983) New records of the freshwater ectoproct Pectinatella magnifica in eastern Texas Tex J Sci 35: 269-271.

Notteghem P (1999) Pectinatella magnifica (Leidy 1851): une nouvelle espèce de Bryozoaires pour la Bourgogne. Rev Period Physiol 74: 12-25.

Notteghem P (2009) Évolution de la distribution de la Pectinatelle, Pectinatella magnifica (Leidy 1851), Bryozoaire d'eau douce, en France et en Europe. Rev Sci Bourgogne-Nature 9-10: 188-197.

Oda S (1974) Pectinatella magnifica occurring in Lake Shoji, Japan. Proc Jap Soc Syst Zool 10: 31-39.

Opravilová V (2005) O výskytu dvou druhů bezobratlých zavlečených do ČR: Dusegia trigrina (Tricladida) a Pectinatella magnifica (Bryozoa). Sborník přírodovědeckého klubu v Brně 25: $39-50$.

Osburn RC (1921) Bryozoa as food for other animals. Science 53: 451-453.

Ricciardi A, Lewis DJ (1991) Occurrence and ecology of Lophopodella carteri (Hyatt) and other fresh-water Bryozoa in the Lower Ottawa River near Montreal, Quebec. Can J Zool 69: 1401-1404.

Riisgård HU, Nielsen KK, Fuchs J, Føns BF, Rasmussen Obst M, et al. (2004) Ciliary feeding structures and particle capture mechanism in the freshwater bryozoan Plumatella repens. Invertebr Biol 123: 155-156.

Rodriguez S, Vergon JP (2002) Pectinatella magnifica Leidy 1851 (Phylactolaemates), un bryozoaire introduit dans le nord Franche-Comté. Bull Fr Pêche Piscic 365-366: 281-296.

Rogick MD (1934) Additions to North American freshwater Bryozoa. Ohio J Sci 34: 316-317.

Rogick MD (1957) Studies on the freshwater Bryozoa. XVIII. Lophopodella carteri in Kentucky. Trans Ky Acad Sci 18: 85-87.

Rogick MD, Schalie H (1950) Studies on fresh-water bryozoa. XVII, Michigan Bryozoa. Ohio J Sci 50: 136-146. 
Seo JE (1998) Taxonomy of the freshwater bryozoans from Korea. Korean J Syst Zool 14: 371-378.

Tittizer T, Schöll F, Banning, Haybach A, Schleuter M (2000) Aquatische Neozoen im Makrozoobenthos der Binnenwasserstraßen Deutschlands. Lauterb 39: 1-72.

Wilcox AW (1906) Locomotion in young Pectinatella. Biol Bull 9: 245-252.
Wood TS (1989) Ectoproct Bryozoans of Ohio. Bull Ohio Biol Surv 8: 170 .

Wood TS (2001) Bryozoans. In: Thorp JH, Covich A (eds): Classification of North American Freshwater Invertebrates. Diego, Academic Press, pp. 505-525.

Zimmer C (1906) Pectinatella magnifica (Leidy) in der Oder. Zool Anz 29: 427-428. 